\title{
Gifted education as a vehicle for enhancing social equality
}

Jennifer Riedl Cross

College of William and Mary, jrcross@wm.edu

Follow this and additional works at: https://scholarworks.wm.edu/educationpubs

Part of the Gifted Education Commons

\section{Recommended Citation}

Cross, Jennifer Riedl, Gifted education as a vehicle for enhancing social equality (2013). Roeper Review, 35(2), 115-123.

https://scholarworks.wm.edu/educationpubs/140

This Article is brought to you for free and open access by the School of Education at W\&M ScholarWorks. It has been accepted for inclusion in School of Education Articles by an authorized administrator of W\&M ScholarWorks. For more information, please contact scholarworks@wm.edu. 
Running Head: Gifted Education and Social Equality

\title{
Gifted Education as a Vehicle for Enhancing Social Equality
}

\author{
Jennifer Riedl Cross, Ph.D. \\ Research Assistant Professor \\ Center for Gifted Education \\ The College of William and Mary \\ P.O. Box 8795 \\ Williamsburg, VA 23187 \\ (757) 221-2414 \\ jrcross@wm.edu
}

Jennifer Riedl Cross is Director of Research at the Center for Gifted Education at the College of William and Mary and co-editor of the Handbook for Counselors Serving Students with Gifts and Talents. 


\begin{abstract}
Considering the benefits that accrue in countries having low levels of social inequality and the harm that accompanies wide disparities in income, it is important to examine any practices or traditions that contribute to inequality. Under some circumstances, gifted education does confer advantages that are not available to all students, particularly when its identification procedures fail to recognize potential in students not in the dominant group or when services improve the educational opportunities only for those who are identified even though all students could benefit. The elimination of age grading, a practice that inhibits the development of potential for many children, including gifted children, is recommended as a solution to the inequality engendered by current practice.
\end{abstract}

Keywords: Gifted education, social inequality, nongraded schools, social justice, defensible gifted education, gifted identification, advocacy 


\section{Gifted Education as a Vehicle for Enhancing Social Equality}

We hold these truths to be self-evident, that all men are created equal, that they are endowed by their Creator with certain unalienable Rights, that among these are Life, Liberty, and the Pursuit of Happiness. - U.S. Declaration of Independence

Americans have embraced the self-evident truth that all men are created equal. The belief has guided us through many transitions as we have explored what is meant by "all" and "men" and "equal" over the years. Although it is popular to claim that all are created equal, there is great latitude for dissent with such a notion. In what ways are we equal? In ability? In status? In value? In access to opportunity? We all may begin equal by some definition, but the opportunity to differentiate ourselves through hard work and determination is a similarly revered tenet of American cultural tradition.

Differentiation has indeed happened in the US, with income inequality at a 40year high. The Gini coefficient, a measure of the inequality of a distribution of incomes in which 0 is maximum equality and 1 is maximum inequality, has increased from .397 in 1967 to .468 in 2009 (U.S. Census Bureau, 2010). Compared to 22 other countries, the US is next to the highest in a comparison of income among the wealthiest $20 \%$ and the poorest $20 \%$. The wealthiest $20 \%$ of Americans make nearly 9 times as much in income as the poorest $20 \%$ (Wilkinson \& Pickett, 2009). Despite the powerful narrative of the American "rags to riches" story, social mobility in the US is not what most Americans believe it to be. Those born into poverty in the US were more likely to still be there at age 40 than those in several other countries (Isaacs, Sawhill, \& Haskins, 2008). 
Greater social inequality is associated with multiple social ills, such as poorer physical and mental health, poorer child well-being, and more violence and drug use (Wilkinson \& Pickett, 2009). In more egalitarian countries, there is less violence, less drug use, better child well-being and health. In her 2010 lecture on "Why Social Inequality Persists," Kate Pickett challenged listeners to "think constantly "What do I do that maintains inequality and what could I do that would push for greater equality?"” This manuscript is an effort to begin that examination in the field of gifted education. Are there things happening in the field that maintain inequality? What can we do to push for greater equality?

\section{A Different Education}

Children of different social classes are likely to attend different types of schools, to receive different types of instruction, to study different curricula, and to leave school at different rates and times. As a result, when children end their schooling, they differ more than when they entered, and society may use these differences to legitimate adult inequalities. (Persell, 2010, p. 85)

Persell summarizes the effects of social inequality on educational experiences. Gifted education is intended to give gifted children a different education, one that is appropriate for their unique needs. But how closely is ability associated with social class? Certainly when arriving at school in Kindergarten, children from lower socioeconomic classes are at a distinct disadvantage in school readiness not felt by their more wealthy peers (Barnett \& Belfield, 2006). A growing body of work suggests that the effect of low socioeconomic status (SES) on intelligence is substantial; environment explains more variance in intelligence scores than genetics for poor children, whereas genetics explains 
more variance than environment among their more advantaged peers (e.g., Harden, Turkheimer, \& Loehlin, 2006; Turkheimer, Haley, Waldron, D'Onofrio, \& Gottesman, 2003). Ability may not count for much among the poor, whose environment overwhelms. This relationship begs the question: Does a different education come about merely because of different ability? Or does social class play a role?

\section{The Evolution of Gifted Education}

The field of gifted education came about because of an identified need. Children with potential were not being served in their classrooms. They were bored, unmotivated, and unchallenged. They spent much of their time in school waiting. This waste of potential was disturbing for parents and researchers who could plainly see the unmet need. Advocacy, backed up by research that supported the call for better education for these unchallenged students, has resulted in an entire discipline of research, graduate programs, professional organizations, and a plethora of products designed to counter the problem of wasted potential. Today, 31 states mandate identification and services for gifted children (National Association for Gifted Children, 2009). Millions of dollars are spent every year in support of gifted education, not only in the schools but also outside the schools, where those seeking information spend money on publications and professional organization memberships and conventions, and parents spend sometimes large amounts of money for educational opportunities for their children. Gifted education is a big enterprise.

\section{Defending an Appropriate Education}

It is difficult to argue against an education that is appropriate for students with great potential. A valuable resource is lost to society when any student does not achieve 
her or his maximum potential. Together, those in gifted education have worked towards an appropriate education for students with high IQ or other indicators of ability or achievement. The overrepresentation of members of the dominant culture in the US, middle to upper class White students, and of Asian students has become a source of concern to many in the field. If all are created equal, why would gifted services be needed only for these students? These concerns have led to alterations in the selection criteria that exclude those who do not "belong," resulting in a lower bar to enter the service arena. Whereas the IQ once deemed "gifted" was 130, 2 standard deviations above the norm, the average IQ of a gifted class today is 115 (Bracken, 2012). "Defensible" gifted education uses multiple criteria for identification, changing our views of who gifted students are and what should be happening for them.

The notion that gifted education must be defended can be found increasingly across the country. A Google search of the term "defensible gifted education" returns 116,000 results - an indication that something is amiss. In the eight decades since Terman's studies of genius, the most recognizable emergence of our field, one would think that consensus would have been built in our society for special services for gifted students. In the same time period, an outpouring of support for students with disabilities has resulted in a broad consensus that their special needs should be met in the schools. No such consensus exists for gifted education. Instead, we find ourselves fighting for defending - our programs. This state of affairs should cause us to look more closely at what we have become and where we are headed. To continue the battleground metaphor, we cede ground when we change our criteria for inclusion, and a new battle is emerging as gifted programs are less able to serve those of the highest ability. I would argue that, 
rather than continually changing our exclusionary criteria, we must examine our goals in gifted education. As we attempt to serve an ever broader ability group of students to satisfy our equality objectives, we lose the capability to serve those at the high end of the spectrum, who may be now bored again in the IQ 115 gifted class. How can we achieve our objective of appropriate education while keeping the equality ideal at the fore?

\section{The Distribution of an Appropriate Education}

For some of our citizens to receive an appropriate education while others do not is antithetical to the American ideal. This is true when gifted students receive an appropriate education and nongifted students do not and in the opposite case, when nongifted students get an appropriate education and gifted students do not. The path from education to occupational status is clear: Higher education leads to higher occupational status

(Fischer, Hout, Sánchez Jankowski, Lucas, Swidler, \& Voss, 1996). With that occupational status comes not only higher income, but also higher prestige. Both income and prestige are linked with general measures of health and well-being (Adler \& Rehkopf, 2008; Fujishiro, Xu, \& Gong, 2010; Judge, Ilies, \& Dimotakis, 2010). This is the American ideal - that all our citizens have the opportunity to attain a comfortable existence, with adequate, even high, income and health care. How achievable this is depends in part on ability, but largely on environmental factors. An education available to all is our society's response to the challenge of equalizing the environment. Ensuring that all students have access to the "best" education is a goal for many. Confusion between "best" and "appropriate" is understandable.

Our public education system was created for a variety of purposes, from religious to political to economic, and it is now the product of generations of shaping to suit these 
various purposes. Different stakeholders wish for different structures and objectives, sometimes mutually supportive and sometimes not. The common belief among many that public education exists to maximize and realize student potential is not supported by the facts on the ground (another battleground metaphor), particularly in this era of accountability. In fact, the Supreme Court has stated as much in the case of Board of Education of the Hendrick Hudson Central School District v. Rowley (1982), in which they make clear that providing an "appropriate" education does not mean "maximizing potential." A society that does not support the development of potential for all risks suppression of aspiration among many who could contribute the most (Ambrose, 2005).

\section{Ability Continuum or Hierarchy?}

Students can be seen as populating a continuum of ability levels, from special needs students to average students to the highest ability gifted students. Each ability level can be assumed to have a maximum potential achievement. With support, the level of achievement will be higher than without. The students at either end of the continuum are assumed to have unique needs, while those in the enormous middle are assumed to not need special accommodations. Among students, the perceived status hierarchy of this ability continuum is not necessarily the same as it is for adults. Rejection of gifted students by their average ability peers is a common phenomenon (T. Cross, 2011). The stigma of giftedness paradigm (Coleman \& T. Cross, 2005) describes the difficulty of life for students at the high end of the ability continuum. Adults, however, are more familiar with the consequences of high ability - higher educational attainment and ultimate occupational status. Their valuing of the continuum turns the horizontal plane into a vertical one. To adults, the ability continuum becomes a status hierarchy. In time, 
children adopt this view as well. Schools, trying to best serve the continuum, are caught in the societal struggle for dominance of the status hierarchy.

Because it serves students at the highest ability levels, gifted education may appear to be the "best" education. Thus, efforts to include more students of varying ability levels in high ability classrooms exist to achieve fairness; to achieve equality of opportunity through access to the best education for all students. A label of "gifted" entitles students to what is believed to be a gold-standard education, in contrast to the silver standard received by all other students. As evidence, many states that require gifted students to be served also require additional training to provide gifted services. In 1991, nearly half of states required certification or endorsement to teach gifted students (Karnes \& Whorton, 1991). Students in gifted education thus have a greater likelihood of being taught by better trained teachers than their nongifted peers.

\section{When Gifted Education Contributes to Inequality}

Under certain circumstances, gifted education plays into the maintenance of the hierarchical structure that undeniably exists in our society. The influence of the dominant culture can be seen in curricula and accountability requirements. When identification of students for gifted services is dependent on success in these arenas, it is unfair to students from other cultures or classes. When services for identified students are of a higher quality than what unidentified students receive, identified students have been given an unfair advantage. When participation is open exclusively to those who have had experiences that only those in the dominant culture or social class have had, an injustice has been done to those with similar potential who lack appropriate experiences because of their language or economic or cultural differences. All these conditions presently exist 
in gifted education to varying degrees. For gifted education to be truly fair, it must address these affronts to our American ideals.

\section{Addressing Affronts to the Equality Ideal}

\section{The Case Against Identification}

As Dai (2011) points out, much of what is currently happening in gifted education is predicated on the notion of "fixed" giftedness. Dai describes the various paradigms in our field, of which the most common is the "Gifted Child Model," which assumes that high ability students can be located and identified through testing and behaviors and served by developing unique curricula that is taught separately from the regular classroom. ${ }^{1}$ Identifying the gifted child has traditionally required testing of ability or achievement. The tests have proven to be a bone of contention, particularly for those advocating for students underrepresented in gifted programming (e.g., Baldwin, 2005; Ford, Harris, Tyson, \& Frazier Trotman, 2002). Test types and cutoff scores that vary from district to district fly in the face of a belief that giftedness can be identified (Ford, 2003). Perhaps due to the significant differences in scores between groups, intelligence tests have been criticized as culturally biased (e.g., Mills \& Tissot, 1995) and achievement tests for discrimination against culturally and linguistically diverse students who may not have had appropriate educational experiences (Ford, 2004). Cognitive factors beyond ability may affect performance in a test intended to identify high ability students (Hearn, 1991). Under conditions of stereotype threat or reminders of in-group low status, members of a group stigmatized as being less capable academically (e.g., women and math, African American and academic ability, low caste), suffered significant

\footnotetext{
${ }^{1}$ Gifted students taught together with their nongifted peers fall under the Differentiation Model of service.
} 
declines in task performance as compared to a control group (Hoff \& Pandey, 2004; Spencer \& Steele, 1999; Steele \& Aronson, 1995).

We have learned that the ability continuum is not singular. Students have multiple abilities and different cultures nurture different abilities (Ford et al., 2002; Gardner, 1983). The dominant culture in the US prizes discipline, order, convergent thinking. Identification practices such as teacher nomination reflect these cultural values (Ford et al., 2002). There are clearly students with exceptional ability who require special services to achieve their potential, but how do we define exceptional ability? Is it intelligence? Is it obedience? Is it test performance? If exceptional ability lies outside the realm of what schools teach, perhaps gifted education has no "dog in this fight." There is no point in identifying abilities that we will not serve in the schools. (T. Cross, \& Coleman, 2005). Or perhaps we should all be examining what schools teach. Reform may need to be in the valued activities promoted in schools.

The isolated gifted. Unless their schools provide differentiation in the regular classrooms, when students are identified as possessing giftedness, they enter into a different academic community from their peers. The Gifted Child Model of gifted education (Dai, 2011) provides services in pull-out programs or self-contained classrooms. Social psychological research suggests that this separation of students from their peers can have positive effects. Students who are told that they are part of an achieving group are more motivated to persist in a difficult task than those told that they are individually capable (Master, 2011; Walton \& Cohen, 2011). These results were found in a general population of preschoolers and college students, not a group of gifted students. It appears that all students can benefit from association with a group reputed to 
be successful at a task. Students may see this benefit as soon as they are admitted to the ranks of "gifted."

There may also be negative effects to pull-out programs, when students leave their friends behind in a regular classroom, a choice some are not willing to make (Henfield, Washington, \& Owens, 2010; Olszewski-Kubilius, 2003). This can be especially true of culturally and linguistically diverse students, who know they may be the only representative of their group in the gifted class. The sacrifice of a comfortable peer group may not be worth the gains in academic opportunities. There is evidence that even contemplating such a choice may affect test performance. In one study, college students told that they would be alone in the future performed significantly worse on intelligence test items than a control group (Baumeister, Twenge, \& Nuss, 2002). The test performance of high ability students in underrepresented groups may not be truly representative when they are aware that they may be the lone member of their cultural group in the class for which they are being tested.

Pull-out programs and self-contained classrooms isolate students from their peers, reducing opportunities for students to interact with a diverse group. Particularly when the majority of students in a gifted program are middle to upper class and White, the inability to interact with a diverse student body can lead to stereotyping and prejudice (Allport, 1954). Contact with diverse community members is necessary to build a sense of unity.

Exclusive benefits. The practice of separating gifted students from their peers for instruction has developed from the belief that they need a different education. As Dai (2011) points out, however, 
there is a consensus in the broad field of education that certain educational goals, traditionally preserved for gifted children, such as deep knowledge, knowledgebased reasoning, complex problem solving, critical thinking, creativity, and leadership, are now considered not only desirable but achievable to some degree by most if not all students. (pp. 713-714)

Defense of programs that offer a means to fulfill educational objectives to one group, but not to all who could benefit, is untenable.

Anecdotal evidence indicates that parents often want their children to be identified for gifted programming so that they can get a better education than they would in the regular classroom. This should not be a part of the logic. Gifted classes should be different to meet the needs of students, but not better than regular classes. It is unjust when gifted education continues to improve its offerings to high ability students while regular students languish. Gifted education that thrives while regular education simply survives contributes to social inequality. Under these circumstances, identified students receive a better education than their peers. John Dewey claimed, "What the best and wisest parent wants for his own child, that must the community want for all of its children. Any other ideal for our schools is narrow and unlovely; acted upon, it destroys our democracy.” (1899, p. 19). Special classes for identified gifted students are likely to confer psychological advantages. As in the case of students who persisted on a difficult task when told they were part of a group (Master \& Walton, 2011; Walton \& Cohen, 2011), students have higher achievement when teachers expect them to perform (Braun, 1976; Brophy, 1986). These advantages should not be exclusive to high ability students when all students could benefit. 


\section{Maximized Potential for Some}

In a study of supporters of gifted education (parents, teachers, coordinators, counselors, administrators, and researchers; $N=341$ ), two groups emerged from an analysis of preferences for gifted education practice (J. Cross, T. Cross, \& Finch, 2009). One group of supporters preferred that gifted students be taught in inclusive environments such as heterogeneous classrooms with differentiated instruction or cluster groups, whereas the other group preferred that they be served in self-contained classes. The authors propose that these preferences reflect the value of community versus individual achievement. Virtually all of the respondents (99\%) agreed that the primary purpose of gifted education is "to help students with gifts and talents achieve their maximum potential," but some believed that this was best accomplished in an exclusive environment rather than an inclusive one. An important question to ask is whether these supporters also believe that the purpose of achieving maximum potential is reserved for gifted education. Assuming that maximized potential is only possible in an exclusive setting results in support for exclusive settings and the development of programs designed to be exclusive.

\section{Appropriate Education for All}

Differentiation. One reason to remove high ability students from the regular classroom is the challenge to teachers of adequately serving the wide ability differences in classes with a heterogeneous student population. Teachers may have difficulty addressing the needs of students who are struggling with a topic at the same time other students have mastered it. Rather than teaching one lesson to the middle ability level, differentiation practices offer a means for teachers to meet all students' needs 
(Tomlinson, 1995). To appropriately differentiate their instruction, teachers must hone their assessment skills and develop strategies for teaching students at various levels of ability and interest. Students are not assumed to have the same ability in all areas and may be grouped differently for various activities. Rather than differentiate instruction for each child individually, cluster grouping allows for students of similar ability levels to be grouped together within a regular classroom (Gentry \& Owen, 1999). Each cluster receives an assignment designed for their ability level, reducing the effort required to differentiate.

When implemented correctly, differentiation approaches provide all students with equal opportunity to achieve to their potential. Differentiation does not require exclusive services for gifted students. They remain with their peers, and may at different times find themselves working together with peers who have advanced abilities in some areas, but not others. All students benefit from efforts at creating an appropriate education to meet their specific needs. The demands on teachers, particularly when they have large classes, are great. Skills can be developed to ease the effort required, but training and commitment are necessary for success (Tomlinson, 2003; VanTassel-Baska \& Stambaugh, 2005).

Differentiation challenges. The theoretical benefits of differentiation are much harder to accomplish in practice. Preservice teachers who had held positive attitudes towards differentiation developed a more negative attitude following their student teaching experience (Moon, Callahan, \& Tomlinson, 1999). Once they realized the effort that would be required to meet the diverse needs of a heterogeneous classroom, the ideal of differentiation looked a bit more daunting. Unfortunately, many teachers and 
administrators believe that they are effectively differentiating instruction, when, in fact, classroom observations find that they are not (Pierce, Cassady, Adams, Speirs Neumeister, \& Cross, 2011).

With the proper commitment of teachers and administrators, adequate training, and reasonable class sizes, differentiation can be an effective way of educating gifted students in the regular classroom. Such instruction has the benefit of regular contact with their peers of all ability levels, together with an appropriate education for all. The Differentiation Model of gifted education is "highly justified and equitable" (Dai, 2011, p. 716). The challenges of properly differentiating, however, will mean that some children, gifted and nongifted, will not get an appropriate education as their teachers struggle to assess their abilities and design suitable lessons. Unless differentiation can be simplified and its proper implementation more easily verified, it is an unacceptable option for maximizing student potential.

Acceleration. Similar to differentiation, acceleration practices consider a student's unique abilities and offer an appropriate education through content- or gradebased acceleration. Despite resounding empirical support for acceleration of either content or grade, there is evidence that it is not utilized as frequently as it could be, particularly among younger children (Wood, Portman, Cigrand, \& Colangelo, 2010). The effects of early grade-skipping are especially positive when done in the early grades, but, unfortunately, this is a practice more likely to occur for females, Whites, and high SES students than their peers (Kuo \& Lohman, 2011). Acceleration, which has the potential to equally benefit all students of high ability, regardless of their group membership (i.e., 
racial, ethnic, SES), contributes to disparate educational opportunity when applied unevenly.

\section{Radical Reform: Eliminating Age Grading}

All these contortions to provide services for children of differing ability levels could be avoided, if instead of focusing on the children, we focused on what it is K-12 students should know. A radical idea (radical in scope, that is) for improving the system is to eliminate age grading. Building our educational system around the subjects and skills we wish students to learn rather than around their chronological age has the potential to eliminate most of the problems for high ability children. All states have developed standards for students to learn at each grade level. If, instead of teaching these standards to specific ages of children, they were taught in a sequence that children can master as they are able, children would move through the K-12 system at their own pace.

Nongraded schools have existed throughout history and were necessary in many rural settings with low school-age populations (Goodlad \& Anderson, 1963). Their popularity has waxed and waned and waxed again (Edson, 1887; Gutiérrez \& Slavin, 1992; Yarborough \& Johnson, 2000). Children in "continuous progress" schools are required to master content before moving on (Mack, 2008; Slavin, 1987), rather than meeting the arbitrary requirement of a specific birthday. Development proceeds at varying rates and emphasizing content over age can benefit those at both ends of the developmental spectrum. Not only can nongraded schools be an effective solution for high ability students, who can move through material at a rapid pace, but they can also benefit students who are not yet developmentally prepared to master the content (Goodlad \& Anderson, 1963; Petrie, Lindauer, Dotson, \& Tountaskis, 2001). 
There is substantial evidence that students in nongraded schools outperform their graded peers (see Gutiérrez \& Slavin, 1992; Slavin, 1987). In their review of research on nongraded elementary school programs, Gutiérrez and Slavin (1992) found the greatest and most consistent achievement gains were seen in schools that focused on the "vertical organization of the school and when nongrading is used as a grouping strategy, but not as a framework for individualized instruction" (p. 368). Properly designed and implemented nongraded programs benefit students academically and emotionally (Ford, 1977; Pavan, 1992; Tanner \& Decotis, 1995). Gutiérrez and Slavin cite Pavan's (1972) dissertation as a model from which to design the "ideal" nongraded school.

A system without age grading would be focused on curriculum development, beginning with the end goal: What should every graduate of the system know? Curricula would then be broken down into as fine a detail as possible, working backwards from that end goal. If, by graduation, students should know X, then prior to that they must have learned $\mathrm{W}$, and before that $\mathrm{V}$, and before that $\mathrm{U}$. Assessment would necessarily be a frequent activity. Schools would take responsibility for children through a certain age, rather than through a certain grade, with current grade-based standards remaining as minimum objectives for each age. A minimum level of achievement could be based on these age-related objectives. Students who have difficulty meeting these objectives would receive additional support, while their high ability peers move on. Students of the same age would be working at various levels in different subject areas. Curricula would need to be developed far beyond the X level for those students who master the content early. Early entrance to college might be appropriate for some students and apprenticeships for others. 
In an education system without age grading, teacher preparation would focus on content specialization, with training in methods for teaching content to broad age ranges. Teachers would become experts in teaching their subject to children of all ability levels, not experts at teaching to a specific age group. The focus of schools would be more on teaching content and less on teaching socialization or "schooling". Educators would be able to focus on maximizing achievement of all students.

If children move to the next level after mastering a subject, regardless of their age, they will never be asked to wait while others catch up. Done properly, students will be able to advance in any subject matter in which they excel, while working at their ability level in other subjects. Students will be with intellectual peers in every subject. Acceleration, the one practice in gifted education that has been best supported empirically as effective (Brody \& Benbow, 1987; Steenbergen-Hu \& Moon, 2011), would happen naturally in such a system. This kind of education takes the focus off what a child "is" - gifted or not - and puts it on what a child can do.

This design offers the opportunity for all students to advance in their areas of ability. The emphasis on keeping together students by chronological age hinders the development of skills for all students, both socially (J. Cross, 2012) and academically. This reform would require dramatic changes to our current system of education, but its benefits would be great. There is a danger in going halfway with such reforms. Palmer (2000) reports on the "poisonous" atmosphere developed in a school that implemented a multiage program within a traditional graded school. Similarly, nongraded elementary schools that send students to traditional secondary schools unprepared for such diverse achievement levels may be doing the students a disservice. 
Other radical reforms might promote equality and a system that maximizes student potential. We must think outside the box to see the possibilities.

\section{Pushing for Greater Equality}

For gifted education to change attitudes about the ability continuum as a status hierarchy, we must think creatively. Differentiation and cluster grouping allow gifted children to learn in the regular classroom. How can these strategies be improved to be simpler for teachers to implement and to be more effective for gifted students? Smaller class sizes are always a need. Gifted education can redirect its efforts to improving all education rather than simply that for identified students. Greater efforts to prepare disadvantaged children before school begins could have tremendous effects on their later academic abilities (Barnett \& Belfield, 2006). Can those of us in the field garner greater support for good preschool education? Borland (2003) asked us to consider gifted education without gifted children. This should be our guiding principle. Rather than focus on the Gifted Child (Dai, 2011), focus on what students need to learn.

We cannot and should not remove services for gifted children, sacrificing their needs to meet our objectives of equality (Robinson, 2003). Baker and Richards (1998) found that, when such services were removed from public schools due to equity concerns, wealthy parents simply moved their gifted children to private education settings, further increasing the inequality in their communities. Instead, we must put together our creative minds to find a solution that provides gifted students and all students what they need to maximize their potential. With such a system, there will be no need to defend our exclusive support for gifted students against charges of elitism.

\section{Is This the End of a Discipline?}


Making social equality the highest priority for gifted education does not mean an end to our discipline. Instead, it requires a transformation of the field, an end to the status quo, and perhaps to the big enterprise gifted education has become. High ability students still need us and what we have learned about them. When all students are getting an excellent education, gifted students will, too. Gifted education can serve as an equalizer in society when its supporters find ways to encourage a better education for all students. Rather than acting to selectively maximize potential in an exclusive environment, gifted education can become a catalyst for greater equality; a vehicle for social improvement. 


\section{References}

Adler, N. F., \& Rehkopf, D. H. (2008). U.S. disparities in health: Descriptions, causes, and mechanisms. Annual Review of Public Health, 29(1), 235-252.

Allport, G. W. (1954). The nature of prejudice. New York, NY: Perseus.

Ambrose, D. (2005). Aspiration growth, talent development, and self-fulfillment in a context of democratic erosion. Roeper Review, 28, 11-19.

Baker, B. D., \& Richards, C. E. (1998). Equity through vouchers: The special case of gifted children. Educational Policy, 12, 363-379.

Baldwin, A. (2005). Identification concerns and promises for gifted students of diverse populations. Theory Into Practice, 44(2), 105-114.

Barnett, W. S., \& Belfield, C. R. (2006). Early childhood development and social mobility. The Future of Children, 16(2), 73-98.

Baumeister, R. F., Twenge, J. M., \& Nuss, C. K. (2002). Effects of social exclusion on cognitive processes: Anticipated aloneness reduces intelligent thought. Journal of Personality and Social Psychology, 83, 817-827.

Board of Education of Hendrick Hudson Central School District v. Rowley 458 U.S. 176 (1982).

Borland, J. H. (2003). The death of giftedness: Gifted education without gifted children. In J. H. Borland (Ed.), Rethinking gifted education (pp. 105-126). New York, NY: Teachers College Press. 
Bracken, B. (2012). Intelligence. In T. L. Cross \& J. R. Cross (Eds.), Handbookfor counselors serving students with gifts and talents (pp. 75-87). Waco, TX: Prufrock Press.

Braun, C. (1976). Teacher expectation: Sociopsychological dynamics. Review of Educational Research, 46, 185-213.

Brody, L. E., \& Benbow, C. P. (1987). Accelerative strategies: How effective are they for the gifted? Gifted Child Quarterly, 31, 105-10.

Brophy, J. (1986). Research Linking Teacher Behavior to Student Achievement: Potential Implications for Instruction of Chapter 1 Students. Designs for Compensatory Education: Conference Proceedings and Papers (Washington, D.C., June 17-18, 1986). (ED 293 914)

Cross, J. R. (2012). Peer relationships. In T. L. Cross \& J. R. Cross (Eds.), Handbookfor counselors serving students with gifts and talents (pp. 409-426). Waco, TX: Prufrock Press.

Cross, T. L., \& Coleman, L. J. (2005). A school-based conception of giftedness. In Sternberg, R. \& Davidson, J. (Eds.). Conceptions of Giftedness (2nd ed., pp. 5263). London: Cambridge University Press.

Cross, J. R., Cross, T. L., \& Finch, W. H. (2010). Maximizing student potential versus building community: An exploration of right-wing authoritarianism, social dominance orientation, and preferred practice among supporters of gifted education. Roeper Review, 32, 235-248.

Cross, T. L. (2010). On the social and emotional lives of gifted children, $4^{\text {th }}$ ed. Waco, TX: Prufrock Press. 
Dai, D. Y. (2011). Hopeless anarchy or saving pluralism? Reflections on our field in response to Ambrose, VanTassel-Baska, Coleman, and Cross. Journal for the Education of the Gifted, 34, 705-730.

Dewey, J. (1899). The school and society. Chicago, IL: University of Chicago Press.

Edson, A. W. (1887). Ungraded vs. graded schools. Journal of Education, 26(19), 291.

Fischer, C. S., Hout, M., Sánchez Jankowski, M., Lucas, S. R., Swidler, A., \& Voss, K. (1996). Inequality by design: Cracking the bell curve myth. Princeton, NJ: Princeton University Press.

Ford, B. E. (1977). Multiage grouping in the elementary school and children's affective development: A review of recent research. Elementary School Journal, 78, 149159.

Ford, D. Y. (2003). Two other wrongs don't make a right: Sacrificing the needs of diverse students does not solve gifted education's unresolved problems. Journal for the Education of the Gifted, 26(4), 283-291.

Ford, D. Y. (2004). Intelligence testing and cultural diversity: Concerns, cautions, and considerations. Storrs, CT: National Research Center on the Gifted and Talented. Retrieved from http://www.eric.ed.gov.proxy.wm.edu/PDFS/ED505479.pdf

Ford, D. Y., Harris III, J., Tyson, C. A., \& Trotman, M. (2002). Beyond deficit thinking. Roeper Review, 24, 52-59.

Fujishiro, K., Xu, J., \& Gong, F. (2010). What does “occupation” represent as an indicator of socioeconomic status?: Exploring occupational prestige and health. Social Science \& Medicine, 71, 2100-2107.

Gardner, H. G. (1983). Frames of mind: The theory of multiple intelligences. New York, 
NY: BasicBooks.

Gentry, M., \& Owen, S. V. (1999). An investigation of the effects of total school flexible cluster grouping on identification, achievement, and classroom practices. Gifted Child Quarterly, 43, 224-243.

Goodlad, J. I., \& Anderson, R. H. (1963). The nongraded elementary school (rev. ed.). New York, NY: Harcourt, Brace \& World.

Gutiérrez, R., \& Slavin, R. E. (1992). Achievement effects of the nongraded elementary school: A best evidence synthesis. Review of Educational Research, 62, 333-376.

Harden, K., Turkheimer, E., \& Loehlin, J. C. (2007). Genotype by environment interaction in adolescents' cognitive aptitude. Behavior Genetics, 37, 273-283. doi:10.1007/s10519-006-9113-4

Hearn, J. C. (1991). Academic and non-academic influences on the college destinations of 1980 high school graduates. Sociology of Education, 64, 158-171.

Henfield, M. S., Washington, A. R., \& Owens, D. (2010). To be or not to be gifted: The choice for a new generation. Gifted Child Today, 32(2), 17-25.

Hoff, K., \& Pandey, P. (2004). Belief systems and durable inequalities: An experimental investigation of Indian caste. Report to the World Bank. Retrieved from http://www-wds.worldbank.org/

Isaacs, J. B., Sawhill, I. V., \& Haskins, R. (2008). Getting ahead or losing ground: Economic mobility in the United States. Report from Brookings Institution and Pew Charitable Trust. Retrieved from http://www.economicmobility.org/assets/pdfs/ 
Judge, T., Ilies, R., \& Dimotakis, N. (2010). Are health and happiness the product of wisdom? The relationship of general mental ability to educational and occupational attainment, health, and well-being. The Journal Of Applied Psychology, 95, 454-468.

Karnes, F. A., \& Whorton, J. E. (1991). Teacher Certification and Endorsement in Gifted Education: Past, Present, and Future. Gifted Child Quarterly, 35, 148-150.

Kuo, Y., \& Lohman, D. F. (2011). The timing of grade-skipping. Journal for the Education of the Gifted, 34, 731-741.

Mack, J. (2008). Continuous progress schools see the "whole child". Education, 129, 324-326.

Master, A. (2011, March). Perceived group membership increases task motivation in young children. Presented at the Biennial Meeting of the Society for Research in Child Development, Montreal.

Mills, C. J., \& Tissot, S. L. (1995). Identifying academic potential in students from under-represented populations: Is using the Ravens' Progressive Matrices a good idea? Gifted Child Quarterly, 39, 209-217.

Moon, T. R., Callahan, C. M., \& Tomlinson, C. A. (1999). The effects of mentoring relationships on preservice teachers' attitudes toward academically diverse students. Gifted Child Quarterly, 43, 56-62.

National Association for Gifted Children. (2009). Gifted by state. Retrieved from http://www.nagc.org/index.aspx ?id=37 
Olszewski-Kubilius, P. (2003). Do we change gifted children to fit gifted programs, or do we change gifted programs to fit gifted children? Journal for the Education of the Gifted, 26, 304-313.

Palmer, S. D. (2005). Culture shock: An inside study of multiage programs. School Administrator, 62(3), 26.

Pavan, B. (1992). The benefits of nongraded schools. Educational Leadership, 50(2), 2225.

Persell, C. H. (2010). Social class and educational equality. In J. A. Banks \& C. A. McGhee Banks (Eds.), Multicultural education: Issues and perspectives $\left(7^{\text {th }}\right.$ ed.; pp. 85-108). Hoboken, NJ: John Wiley \& Sons.

Petrie, G., Lindauer, P., Dotson, K., \& Tountaskis, M. (2001). The nongraded middle school: Can it improve life for early adolescents? Education, 121, 781-786.

Pickett, K. (2010). Why social inequality persists. Royal Society for the Encouragement of the Arts. Retrieved from http://www.youtube.com/watch?v=MBzYYeAolAA

Pierce, R. L., Cassady, J. C., Adams, C. M., Speirs Neumeister, K. L, Dixon, F. A., \& Cross, T. L. (2011). The effects of clustering and curriculum on the development of gifted learners' math achievement. Journal for the Education of the Gifted, 34, 569-594.

Robinson, N. M. (2003). Two wrongs do not make a right: Sacrificing the needs of gifted students does not solve society's unsolved problems. Journal for the Education of the Gifted, 26, 251-273.

Slavin, R. E. (1987). Ability grouping and student achievement in elementary schools: A best-evidence synthesis. Review of Educational Research, 57, 293-336. 
Spencer, S. J., \& Steele, C. M. (1999). Stereotype threat and women's math performance. Journal of Experimental Social Psychology, 35, 401-409.

Steele, C. M., \& Aronson, J. (1995). Stereotype threat and the intellectual test performance of African Americans. Journal of Personality \& Social Psychology, 69(5), 797-811.

Steenbergen-Hu, S., \& Moon, S. M. (2011). The effects of acceleration on high-ability learners: A meta-analysis. Gifted Child Quarterly, 55, 39-53.

Tanner, C., \& Decotis, J. D. (1995). The effects of continuous-process nongraded primary school programs on student performance and attitudes towards learning. Journal of Research \& Development in Education, 28(3), 135-144.

Tomlinson, C. A. (1995). Differentiating instruction for advanced learners in the mixedability middle school. ERIC Digest E536. (ED389141)

Tomlinson, C. (2003). Fulfilling the promise of the differentiated classroom: Tools and strategies for responsive teaching. Alexandria, VA: Association for Supervision and Curriculum Development.

Turkheimer, E., Haley, A., Waldron, M., D'Onofrio, B., \& Gottesman, I. I. (2003). Socioeconomic status modifies heritability of iq in young children. Psychological Science, 14, 623-628.

U.S. Census Bureau, Current Population Survey, 1968 to 2010 Annual Social and Economic Supplements. Retrieved from http://www.census.gov/hhes/www/income/data/historical/inequality/taba2.pdf VanTassel-Baska, J., \& Stambaugh, T. (2005). Challenges and possibilities for serving gifted learners in the regular classroom. Theory Into Practice, 44, 211-217. 
Walton, G. M., \& Cohen, G. L. (2011). Sharing motivation. In D. Dunning (Ed.), Social motivation (pp. 79-101). New York, NY: Taylor \& Francis.

Wilkinson, R. G., \& Pickett, K. (2009). The spirit level: Why more equal societies almost always do better. London, England: Allen Lane.

Wood, S., Portman, T., Cigrand, D. L., \& Colangelo, N. (2010). School counselors' perceptions and experience with acceleration as a program option for gifted and talented students. Gifted Child Quarterly, 54, 168-178.

Yarborough, B. H., \& Johnson, R. A. (2000). Nongraded schools: Why their promise has not been realized and should be reconsidered. Contemporary Education, 71(3), $42-48$. 